\title{
THE IMPACT OF CULINARY TOURISM ON THE ECONOMY OF COASTAL COMMUNITIES IN TIRAM BEACH NAGARI TAPAKIS SUB DISTRICT ULAKAN TAPAKIS PADANG PARIAMAN REGENCY WEST SUMATERA PROVINCE
}

\section{DAMPAK WISATA KULINER TERHADAP PEREKONOMIAN MASYARAKAT PESISIR DI PANTAI TIRAM NAGARI TAPAKIS KECAMATAN ULAKAN TAPAKIS KABUPATEN PADANG PARIAMAN PROVINSI SUMATERA BARAT}

\author{
Dela Sintya ${ }^{\mathbf{1}}$, Trisla Warningsih ${ }^{\mathbf{1}}$, Hamdi Hamid ${ }^{1}$ \\ ${ }^{1}$ Sosial ekonomi Perikanan Fakultas Perikanan dan Kelautan, Universitas Riau, Jl. HR \\ Soebrantas Km 12,5 Simpang Baru, Panam - Pekanbaru, Indonesia 28293 - Correspondence \\ Author : dela.sintya@yahoo.com
}

\begin{tabular}{|c|c|}
\hline $\mathrm{L}$ & B S T R A C T \\
\hline & \multirow[b]{2}{*}{$\begin{array}{l}\text { This study aimed to utilize the fish bone waste from different types of fish, } \\
\text { Pangasius sp., Clarias sp., Paraplotosus sp. as a high calcium of bone flour and } \\
\text { determine the quality characteristics of fish bone flour which was produced. The } \\
\text { method used was a non-factorial Completely Randomized Design (CRD), with } \\
\text { different types of fish bones as treatments which consisting of } 3 \text { levels: Pangasius } \\
\text { sp. bone (Tp), Clarias sp. bone (Tl), and Paraplotosus sp. bone (Ts) with } 3 \\
\text { replications and } 9 \text { units of experimental units. The parameters tested were } \\
\text { organoleptic, proximate analysis, calcium, phosphorus and whiteness degrees. The } \\
\text { results showed that the Pangasius sp. bone flour (Tp) was the best treatment with } \\
\text { characteristics of brilliant appearance, the distinctive aroma of fish was still felt, } \\
\text { smooth and dry texture, as well as whiteness degrees that the best treatment in } \\
\text { walking catfish bone flour with value } 81.30 \% \text {, referred to whiteness degrees of } \\
\text { flour, it is below the range of } 80-90 \% \text {. Meanwhile the best proximate value was } \\
\text { obtained in Paraplotosus sp. bone treatment (Ts) with moisture, ash, fat, protein, } \\
\text { carbohydrate, calcium and phosphorus content was } 5.71 \%, 54.60 \%, 2.57 \%, 25.21 \% \text {, } \\
10.83 \%, 38.4 \% \text {, and } 33.9 \% \text {. }\end{array}$} \\
\hline & \\
\hline
\end{tabular}

\section{PENDAHULUAN}

Salah satu objek wisata alam yang menawarkan kuliner khas masakan Minangkabau adalah wisata kuliner Pantai Tiram. Wisata Kuliner Pantai Tiram resmi dibuka pada tahun 2007 dan mulai mengalami pengembangan pada tahun 2014. Secara geografis wisata kuliner Pantai Tiram terletak di wilayah Nagari Tapakis, Kecamatan Ulakan Tapakis, Kabupaten Padang Pariaman, Provinsi Sumatera Barat. Berjarak kurang lebih 12 kilometer di Bandara Internasional Minangkabau (Azrianto, 2014).

Wisata kuliner Pantai Tiram menjadi salah satu daya tarik wisata di Sumatera Barat yang mampu mendatangkan manfaat terhadap perekonomian masyarakat setempat. Wisata kuliner Pantai Tiram merupakan olahan yang berupa masakan berupa lauk pauk yang berasal dari ikan laut. Masakan utama wisata kuliner ini adalah gulai 
kepala ikan karang, selain itu juga ada gulai anak ikan laut, sala lauk, rakit udang, dan rakit kepiting.

Pada awalnya di Pantai Tiram hanya ada satu rumah makan yaitu rumah makan Ernawati yang sekarang dikenal pondok lesehan Ernawati namun seiring dengan pengembangan serta pelatihan yang dilakukan dinas terkait maka saat ini sudah ada 12 rumah makan yang buka setiap hari. Jumlah pengunjung wisata kuliner di Pantai Tiram meningkat dari 2.660 orang di tahun 2012 menjadi 6.850 orang di tahun 2017 dengan pertumbuhan rata-rata 61\% (Kenagarian Tapakis, 2017).

Pengunjung yang datang untuk menikmati kuliner serta keindahan di Pantai Tiram akan memberikan dampak ekonomi dengan adanya kegiatan-kegiatan yang ada di Pantai Tiram. Hal ini secara tidak langsung menunjukkan dampak positif pariwisata terhadap pertumbuhan rumah makan khas Minang. Kondisi tersebut tentu memberikan efek positif terhadap perekonomian masyarakat.

Dalam hal ini dampak ekonomi tentu harus ditinjau dalam pengembangan wisata kuliner di Pantai Tiram sehingga akan diketahui bagaimana kawasan wisata kuliner ini akan mempengaruhi dan memberikan dampak ekonomi terhadap masyarakat sekitar kawasan wisata kuliner Pantai Tiram, Nagari Tapakis, Kecamatan Ulakan Tapakis, Kabupaten Padang Pariaman, Provinsi Sumatera Barat.

Berdasarkan urairan ini, maka permasalahan yang akan di lihat dalam penelitian ini adalah: 1) Bagaimana karakteristik pengunjung, pelaku usaha, nelayan dan masyarakat pesisir di kawasan wisata kuliner Pantai Tiram. 2) Bagaimana dampak ekonomi kegiatan wisata kuliner Pantai Tiram.

\section{METODE PENELITIAN}

\section{Lokasi dan Waktu Penelitian}

Penelitian ini telah dilaksanakan pada tanggal 25 Maret sampai 08 April 2018 yang berlokasi di Pantai Tiram Nagari Tapakis Kecamatan Ulakan Tapakis Kabupaten Padang Pariaman Provinsi Sumatera Barat.

\section{Populasi dan Responden Penelitian}

Populasi pada penelitian ini adalah pengunjung 7.416 orang menggunakan rumus Slovin, pelaku usaha rumah makan 12 orang, nelayan 5 orang dan masyarakat Korong Tiram. Pengambilan sampel pengunjung menggunakan rumus Slovin. Responden pengunjung dari hasil rumus Slovin adalah 99 orang dengan menggunakan teknik accidental sampling. Responden pelaku usaha rumah makan dan nelayan di kawasan wisata kuliner terdapat 12 orang pelaku usaha dan 5 orang nelayan dengan menggunakan, menggunakan teknik sensus. Responden dari masyarakat pesisir adalah masyarakat Korong Tiram, dengan 100 kepala keluarga, diambil 10\% dari jumlah kepala keluarga (KK) dengan menggunakan teknik simple random sampling,

1. Untuk mengetahui karakteristik pengunjung, pelaku usaha, nelayan dan msyarakat lokal maka dapat dianalisis secara deskriptif. Analisis Deskriptif berguna untuk mengidentifikasi karakteristik responden yakni seperti umur, jenis kelamin, tingkat pendidikan, frekuensi kunjungan, biaya operasional, pendapatan dan pekerjaan.

2. Untuk mengetahui dampak ekonomi dari kegauatan wisata kuliner Pantai Tiram maka dapat dianalisis menggunakan analisis damapak berganda (multiplier effect). Dampak ekonomi diukur menggunakan Ratio Income Multiplier, yaitu nilai yang menunjukkan seberapa besar dampak langsung yang dirasakan dari pengeluaran pengunjung berdampak terhadap perekonomian lokal, digunakan rumus :

Ratio Income Multiplier tipe II

$$
\underline{\mathrm{D}+\mathrm{N}+\mathrm{U}}
$$

$\mathrm{D}$

Dimana :

$\mathrm{D}$ : pendapatan lokal yang diperoleh secara langsung (rupiah)

$\mathrm{N}$ : pendapatan lokal yang diperoleh secara tidak langsung (rupiah)

$\mathrm{U}$ : pendapatan lokal yang diperoleh secara lanjutan (rupiah)

Kriteria-kriteria dari hasil yang didapat adalah sebagai berikut :

1. Apabila nilai-nilai tersebut kurang atau sama dengan nol $(\leq 0)$, maka lokasi wisata tersebut belum mampu memberikan dampak ekonomi terhadap kegiatan wisatanya, 
2. Apabila nilai-nilai tersebut diantara nol dan satu $(0<\mathrm{x}<1)$, maka lokasi wisata tersebut memliki dampak ekonomi yang rendah, dan

3. Apabila nilai-nilai tersebut besar dari satu $(>1)$, maka lokasi wisata tersebut telah mampu memberikan dampak ekonomi terhadap kegiatan wisatanya.

\section{HASIL DAN PEMBAHASAN}

Kecamatan Ulakan Tapakis adalah salah satu dari 17 Kecamatan yang terdapat di Kabupaten Padang Pariaman, Provinsi Sumatera Barat. Kecamatan Ulakan Tapakis merupakan hamparan daratan rendah terletak di Pantai Barat Pulau Sumatera dengan ketinggian 2 meter di atas permukaan laut, dengan luas wilayah $38,85 \mathrm{~km}^{2}$ dan memiliki panjang garis pantai 7,5 km. Batas wilayah Kecamatan Ulakan Tapakis sebelah Utara berbatasan dengan Kecamatan Nan Sabaris. Sebelah Selatan berbatasan dengan Kecamatan Batang Anai. Sebelah Timur berbatasan dengan Kecamatan Lubuk Alung. Sebelah Barat berbatasan dengan Samudera Indonesia, dengan titik koordinat $0^{\circ} 18^{\prime} 30^{\prime \prime}-0^{\circ} 50^{\prime}$ LS dan 99 $56^{\prime}$ $100^{\circ} 28^{\prime}$ BT (Kasai, 2013)

Wisata kuliner Pantai Tiram ini banyak dikunjungi oleh wisatawan pada saat jam makan siang hingga sore hari. Namun lebih ramai pada siang hari, terutama saat akhir pekan dan hari libur. Wisatawan yang datang ke kawasan wisata kuliner ini umumnya adalah rombongan keluarga, rombongan pegawai negeri sipil, rombongan organisasi dan rombongan mahasiswa yang menggunakan kendaraan mobil dan motor.

Pengunjung yang datang ke wisata kuliner Pantai Tiram ini tidak dikenakan biaya tiket masuk, namun dikenakan biaya parkir sebesar Rp3.000,00 untuk roda 4 (empat) dan Rp2.000,00 roda 2 (dua). Di kawasan wisata kuliner Pantai Tiram ini terdapat 12 rumah makan yang berdiri di tanah mereka masing-masing. Rumah makan ini menyediakan menu masakan khas minang, dengan menu utama adalah gulai kepala ikan karang. Selain itu, ada juga menu lainnya seperti gulai anak ikan laut, sala lauk, rakit udang dan rakit kepiting. Rumah makan berbentuk pondok-pondok yang dapat melihat pemandangan Pantai Tiram. Sehingga pengunjung dapat menikmati masakan khas minang dengan nikmat.

Di kawasan wisata kuliner Pantai Tiram ini memiliki fasilitas seperti toilet umum, mushola dan landmark yaitu jembatan yang menghubungkan antara rumah makan ke tepi Pantai Tiram. Rumah makan yang ada di kawasan wisata kuliner Pantai Tiram merupakan usaha yang dimiliki oleh masyarakat sekitar wisata kuliner Pantai Tiram. Masyarakat sekitar kawasan Pantai Tiram tidak merasa terganggu adanya wisata kuliner Pantai Tiram ini, karena dapat meningkatkan perekonomian masyarakat sekitar. Berdasarkan hasil wawancara, menurut pengunjung sikap masyarakat disekitar wisata kuliner Pantai Tiram dinilai baik.

\section{Karakteristik Pengunjung}

Pengunjung yang datang ke wisata kuliner Pantai Tiram berasal dari berbagai daerah di Provinsi Sumatera Barat, seperti Pariaman, Padang, Bukittinggi, Batusangkar, Payakumbuh, Pasaman Barat, Solok dan Padang Panjang. Selain itu, pengunjung juga ada yang berasal dari luar Provinsi Sumatera Barat seperti Taluk Kuantan, Kampar, Pekanbaru dan Medan. Tujuan utama pengunjung untuk datang ke wisata kuliner Pantai Tiram adalah menikmati masakan khas minang sambil menikmati keindahan suasana Pantai Tiram. Umumnya pengunjung yang datang adalah rombongan keluarga yang berkisar antara 2-14 orang dan juga ada rombongan teman kerja 3-6 orang. Pengunjung yang datang menggunakan kendaraan pribadi seperti mobil dan sepeda motor. Karena jarak tempuh untuk mencapai wisata kuliner Pantai Tiram ini umumnya ditempuh dalam waktu 1-6 jam.

Pengunjung yang datang ke wisata kuliner Pantai Tiram mendominasi pada usia 28-33 tahun. Pekerjaan pengunjung wisata kuliner Pantai Tiram ini paling banyak adalah Pegawai Negeri Sipil (PNS) dengan pendapatan diatas Rp 2.000.000,00, sedangkan untuk tingkat pendidikan terakhir pengunjung wisata kuliner Pantai Tiram adalah sarjana.

\section{Karakteristik Pelaku Usaha}


Pelaku usaha yang ada di kawasan wisata kuliner Pantai Tiram Nagari Tapakis Kecamatan Ulakan Tapakis umumnya masyarakat lokal yang tinggal di sekitar wisata kuliner Pantai Tiram. Jenis usaha yang dimiliki adalah rumah makan masakan khas minang dengan menyediakan menu utama

Tabel 1. Dampak ekonomi langsung pelaku usaha rumah makan.

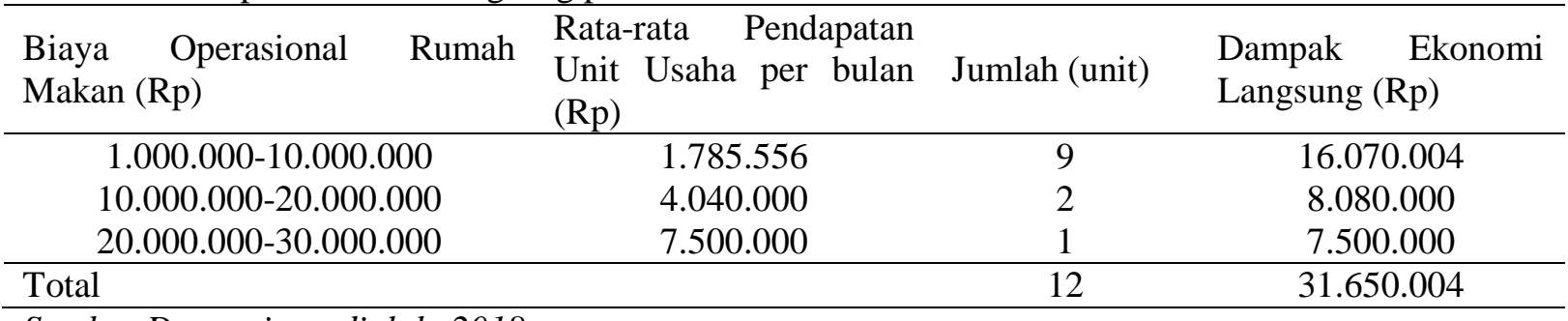

Sumber Data primer diolah, 2018

Tabel 2. Dampak ekonomi langsung jasa parkir

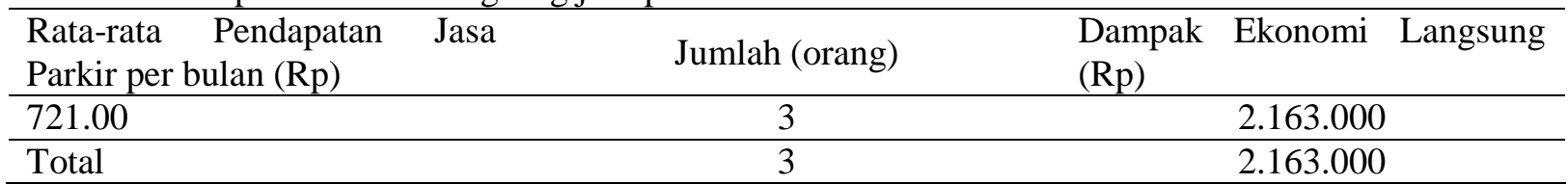

Sumber Data primer diolah, 2018

Tabel 3. Total dampak ekonomi langsung

\begin{tabular}{lc}
\hline Jenis Usaha & Dampak Ekonomi Langsung (Rp) \\
\hline Rumah Makan & 31.650 .004 \\
Jasa Parkir & 2.163 .000 \\
\hline Total & 33.813 .004 \\
\hline
\end{tabular}

Sumber Data primer diolah, 2018

Tabel 4. Dampak ekonomi tidak langsung

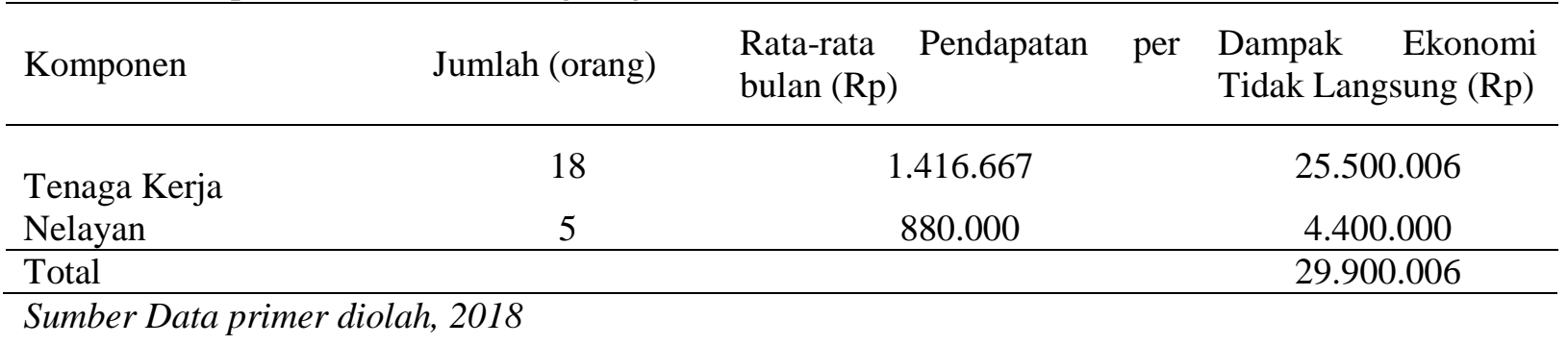

Tabel 5. Dampak ekonomi lanjutan

\begin{tabular}{|c|c|c|c|c|}
\hline Tenaga Kerja & Jumlah (orang) & $\begin{array}{l}\text { Rata-rata Total } \\
\text { Pengeluaran } \\
\text { Kerja/bulan }(\mathrm{Rp}\end{array}$ & $\begin{array}{r}\text { Keseluruhan } \\
\text { Tenaga }\end{array}$ & $\begin{array}{l}\text { Dampak } \\
\text { Lanjutan (Rp) }\end{array}$ \\
\hline
\end{tabular}

\begin{tabular}{lccc}
\hline Rumah Makan & 18 & 1.500 .000 & 12.420 .00 \\
Jasa Parkir & 3 & 721.000 & 1.341 .00 \\
\hline Total & & 13.761 .000 \\
\hline
\end{tabular}


Sumber Data primer diolah, 2018

gulai kepala ikan karang. Sedangkan menu lainnya seperti gulai anak ikan laut, sala lauk, rakit udang dan rakit kepiting.

Usia pelaku usaha yang di kawasan wisata kuliner Pantai Tiram berkisar antara 41-43 tahun. Tingkat pendidikan terakhir yang dimiliki oleh pelaku usaha umumnya adalah sampai tingkat SMA/Sederajat. Biaya operasional pelaku usaha rumah makan rata-rata antara $\mathrm{Rp} 1.000 .000,00-\mathrm{Rp}$ $10.000 .000,00$ dengan rata pendapatan rata-rata diatas $\mathrm{Rp} 2.000 .000 .00 /$ bulan. Pendapatan tersebut diperoleh dari pengeluaran konsumsi pengunjung selama berada di kawasan wisata kuliner Pantai Tiram.

\section{Karakteristik Nelayan}

Nelayan berada disekitar kawasan wisata kuliner Pantai Tiram umumnya adalah masyarakat lokal Korong Tapakis, Nagari Tapakis. Dari hasil penelitian yang dilakukan, usia nelayan rat-rata 3541 dan 49-55 tahun. Tingkat pendidikan terakhir umumnya hingga lulus Sekolah Menengah Atas (SMA). rata-rata pendapatannya $\mathrm{Rp} 500.000,00-\mathrm{Rp} 1.000 .000,00 / \mathrm{bulan}$.

\section{Karakteristik Masyarakat Lokal}

Kawasan wisata kuliner Pantai Tiram tepatnya berada di Korong Tiram Kecamataan Ulakan Tapakis. Korong Tiram memiliki 100 kepala keluarga yang rentang usianya 29 tahun sampai dengan 48 tahun, namun paling banyak 34-38 tahun. Dari hasil penelitian yang dilakukan, tingkat pendidikan terakhir umumnya hingga lulus Sekolah Menengah Atas (SMA) dengan rata-rata pendapatannya diatas $\mathrm{Rp} 2.000 .000 .00 /$ bulan, dengan jenis pekerjaan rata-rata adalah wiraswasta.

\section{Dampak Ekonomi Langsung}

Untuk mengetahui dampak ekonomi langsung di kawasan wisata kuliner Pantai Tiram dapat dilihat pada Tabel 1, 2 dan 3. Berdasarkan Tabel 1 dapat dilihat bahwa dampak ekonomi langsung dari pelaku usaha rumah makan di kawasan wisata kuliner Pantai Tiram Nagari Tapakis Kecamatan Ulakan Tapakis adalah sebesar Rp 31.650.004,00 per bulan didapat dari pendapatan pelaku usaha yang diterima dari pengeluaran pengunjung di Kawasan wisata kuliner Pantai Tiram. Berdasarkan Tabel 2 dapat dilihat dampak ekonomi langsung dari jasa parkir adalah sebesar Rp 2.163.000,00 per bulan. Berdasarkan Tebel 3 dapat dilihat total dampak ekonomi langsung di kawasan wisata kuliner Pantai Tiram sebesar Rp 33.813.004,00 per bulan.

\section{Dampak Ekonomi Tidak Langsung}

Untuk mengetahui dampak ekonomi tidak langsung di kawasan wisata kuliner Pantai Tiram dapat dilihat pada Tabel 4. Pada Tabel 4 dapat dilihat dampak ekonomi tidak langsung terbesar di kawasan wisata kuliner Pantai Tiram Nagari Tapakis diperoleh dari pendapatan tenaga kerja di restoran wisata kuliner Pantai Tiram sebesar Rp 25.500.006,00 per bulan, sedangkan pendapatan nelayan memperoleh dampak ekonomi tidak langsung sebesar Rp4.400.000,00 per bulan. Sehingga total dampak ekonomi tidak langsung keseluruhan di kawasan wisata kuliner pantai Tiram sebesar Rp 29.900.006,00.

\section{Dampak Ekonomi Lanjutan}

Untuk mengetahui dampak ekonomi lanjutan di kawasan wisata kuliner Pantai Tiram dapat dilihat pada Tabel 5. Pada Tabel 5 dapat dilihat, dampak ekonomi lanjutan diperoleh di kawasan wisata kuliner Pantai Tiram sebesar Rp13.761.000,00 per bulan. Perhitungan dampak ekonomi lanjutan didapat dengan cara mengalikan rata-rata total keseluruhan pengeluaran tenaga kerja, lalu rata-rata total keseluruhan pengeluaran tenaga kerja, dengan proporsi pengeluaran di kawasan wisata dan jumlah populasi dari tenaga kerja.

\section{Nilai Efek Pengganda (Multiplier Effect)}


Dampak ekonomi yang terjadi di kawasan wisata kuliner Pantai Tiram dari pengeluaran pengunjung dapat di ukur dengan menggunakan nilai efek pengganda berdasarkan Ratio Income Multiplier Tipe II, yaitu nilai yang menunjukkan seberapa besar dampak ekonomi langsung yang dirasakan dari pengeluaran pengunjung terhadap perekonomian lokal. Nilai pengganda pada penelitian ini fokus dalam menghitung dampak langsung (direct effect), dampak tidak langsung (indirect effect), dan dampak lanjutan (induced effect) yang terjadi di kawasan wisata kuliner Pantai Tiram. Sesuai dengan rumusan Ratio Income Multiplier Tipe II yang menggunakan komponenkomponen dampak langsung, dampak tidak langsung, dan dampak lanjutan, dimana dampak langsung adalah pendapatan pelaku usaha yang ditambahkan pengeluaran kemudian ditambahkan pengeluaran tenaga kerja selama di kawasan wisata. Hasil tersebut dibagi dengan pendapatan pelaku usaha, sehingga didapatkan nilai Ratio Income Multiplier tipe II di kawasan wisata kuliner Pantai Tiram adalah 2.2. Nilai Ratio Income Multiplier tipe II di kawasan wisata kuliner Pantai Tiram sebesar 2.2 artinya setiap peningkatan Rp10.000,00 penerimaan unit usaha maka akan mengakibatkan peningkatan sebesar Rp22.000 pada pendapatan pemilik unit usaha, pendapatan tenaga kerja, pendapatan nelayan, dan pengeluaran konsumsi tenaga kerja dalam putaran perekonomian di tingkat lokal.

Dari nilai Ratio Income Multiplier tipe II yang didapatkan, yakni 2.2 dimana nilai tersebut besar dari $1(>1)$. Jika dilihat dari kriteria yang sudah ditentukan, maka nilai Ratio Income Multiplier tipe II tersebut dapat diartikan bahwa kawasan wisata kuliner pantai Tiram telah mampu memberikan dampak ekonomi, baik dampak langsung, tidak langusung, maupun dampak lanjutan dalam kegiatan wisatanya. Berdasarkan hasil Ratio Income Multiplier tipe II yang ada di kawasan wisata kuliner Pantai Tiram menunjukkan bahwa kegiatan wiasa kuliner ini sangat berpotensi untuk meningkatkan kegiatan perekonomian khususnya masyarakat sekitar.

Pada penelitian Amanda (2009) di Pantai Bandulu pada tahun 2009 meneliti mengenai efek pengganda yang dihasilkan dari kegaiatan wisata Pantai Bandulu. Nilai Ratio Income Multiplier tipe II adalah sebesar 1.63. Penelitian Dristasto dan Anggraeni (2003) menjelaskan dampak ekonomi Pulau Tidung dengan nilai Ratio Income Multiplier tipe II sebesar 1.59. Penelitian Prasetyo (2011) melakukan penelitian di Pulau Pramuka memiliki Ratio Income Multiplier tipe II sebesar 1.8. Penelitian yang dilakukan Wolok (2016) di Batubarani Gorontalo memiliki nilai Ratio Income Multiplier tipe II sebesar 1,97. Penelitian yang dilakukan Mutty (2015) di Lembang Bandung memiliki nilai Ratio Income Multiplier tipe II sebesar 2.1 dan penelitian yang dilakukan oleh Milasari (2010) di Taman Wisata Tirta Sanita memilki nilai Ratio Income Multiplier tipe II sebesar 1.37. Bila dibandingkan dengan nilai Ratio Imcome Multiplier tipe II wsiata kuliner Pantai Tiram, dapat disimpulkan bahwa dampak peningkatan penerimaan di kawasan wisata kuliner Pantai Tiram terhadap pendapatan pemilik usaha rumah makan, jasa parkir, tenaga kerja, nelayan, dan pengeluaran tenaga kerja dan jasa parkir di tingkat ekonomi lokal adalah cukup besar.

\section{KESIMPULAN}

Wisatawan sering berkunjung berusia 28-33 tahun, berpendidikan sarjana dan mayoritas pengunjung berprofesi sebagai PNS dengan pendapatan >Rp2.000.000,00/bulan. Pelaku usaha memiliki usia 41-43 tahun yang pendapatannya antara Rp 1.000.000,00-Rp 10.000.000,00/bulan, dengan pendidikan SMA. Nelayan rata-rata memliki usia 35-41 tahun dan 49-55 tahun rata-rata pendapatannya antara Rp 500.000,00-Rp 1.000.000,00/bulan, berpendidikan terakhir SMA. Masyarakat lokal berusia 44-48 tahun, rata-rata pendapatannya $>\mathrm{Rp2} .000 .000,00$ per bulan, dimana rata-rata pendidikan terakhir SMA dan mayoritas berprofesi sebagai wiraswasta.

Aktivitas wisata kuliner Pantai Tiram telah memberikan dampak ekonomi yang dilihat dari dampak langsung (direct effect), dampak tidak langsung (indirect effect), dan dampak lanjutan (induced effect). Dari hasil penelitian yang dilakukan, didapatkannya nilai Ratio Income Mulitiplier tipe II sebesar 2.2. 


\section{REKOMENDASI}

Pemerintah dapat lebih meningkatkan promosi terhadap wisata kuliner Pantai Tiram melalui media cetak dan elektronik dan mengoptimalkan pengembangan wisata kuliner Pantai Tiram agar lebih meningkatkan jumlah pengunjung. Pihak pengelola bersama pemerintah daerah diharapkan dapat bekerja sama meningkatkan sarana dan prasarana yang telah ada (melakukan perbaikan berkala untuk musholla, toilet, dan lainnya). Tenaga kerja yang bekerja di kawasan wisata kuliner Pantai Tiram di haruskan masyarakat lokal atau masyarakat sekitar kawsan wisata kuliner Pantai Tiram. Pengelola, pengunjung, dan warga sekitar khususnya, diharapkan dapat menjaga keberlangsungan wisata kuliner Pantai Tiram demi keberlanjutan kawasan wisata tersebut. Hasil penelitian ini dapat dijadikan sebagai tambahan referensi dalam penyusunan penelitian selanjutnya atau penelitian-penelitian sejenisnya.

\section{DAFTAR PUSTAKA}

Amanda. (2009). Analisis Dampak Ekonomi Wisata Bahari Terhadap Pendapatan Masyarakat Lokal Studi Kasus Pantai Bandulu Kabupaten Serang Provinsi Banten. Tersedia dari Skripsi. Institut Pertanian Bogor. Bogor: tidak diterbitkan

Azrianto. (2014, 4 Maret). Wisata Kuliner Pantai Tiram Kab. Padang Pariaman. Tulisan pada https:/rangkiangbudaya.wordpress.com/2014/03/04/wisata-kuliner-pantai-tiram-kab-padangpariaman/

Kasai. (2013,9). Profil Kecamatan Ulakan Tapakis. Tulisan pada http:/anakkasai.blogspot.com/2013/09/profil-kecamatan-ulakan-tapakis.html

Kanagarian Tapakis. (2017). Data Pengunjung Wisata Kuliner Pantai Tiram dari Tahun 2012 sampai 2017. Padang: Padang Pariaman

Lemhnas. (2012). Pengembangan Ekonomi Kreatif Guna Menciptakan Lapangan Kerja dan Mengentasakan Kemiskinan dalam Rangka Ketahanan Nasional. Jurnal Kajian Lemhanas, 14, 4-11

Milasari. (2010). Analisis Dampak Ekonomi Kegiatan Wisata Alam (Studi Kasus: Taman Wisata Tirta Sanita, Kabupaten Bogor). Tersedia dari Skripsi. Fakultas Ekonomi dan Manajemen Institut Pertanian Bogor. Bogor: tidak diterbitkan

Mutty. (2015). Analisis Dampak Ekonomi Kegiatan Wisata Alam (Studi Kasus: Floating Market Lembang, Bandung). Tersedia dari Skripsi. Institut Pertanian Bogor. Bogor: tidak diterbitkan

Prasetyo. (2011). Analisis Dampak Ekonomi Wisata Bahari Terhadap Masyrakat di Pulau Pramuka Taman Nasional Kepulauan Seribu. Tersedia dari Skripsi. Fakultas Kehutanan Institut Pertanian Bogor. Bogor: tidak diterbitkan

Satria, A. (2004, 14 Oktober). Pengantar Sosiologi Masyarakat Pesisir. Jakarta: Pusako Cisendo

Surdayana. (2009). Perkembangan Industri Makanan (Kuliner). Disampaikan pada Seminar CREPS 2009, yang diselenggarakan oleh Program Studi Manajemen Industri Katering, Fakultas Pendidikan dan Ilmu Sosial, Universitas Pendidikan Indonesia Bandung

Wijayanti, Pini. (2009). Analisis Ekonomi dan Kebijakan Pengelolaan Wisata Alam Berbasis Masyarakat Lokal di Kabupaten Administrasi Kepulauan Seribu Provinsi DKI Jakarta. Tersedia dari Tesis. Program Pascasarjana Institut Pertanian Bogor. Bogor: tidak diterbitkan 